\title{
Bacterial Synthesis of Nanoparticles: Current Trends in Biotechnology and Biomedical Fields
}

\section{Capuzzo AM*}

Department of Veterinary Medicine, University of Milan, Italy

*Corresponding author: Arnaud Martino Capuzzo, Department of Veterinary Medicine, University of Milan, Italy, Tel: 00393489068620; Email: arnaudcapuzzo@gmail.com

Research Article

Volume 4 Issue 1

Received Date: April 14, 2021

Published Date: June 23, 2021

DOI: $10.23880 /$ aabsc- 16000161

\section{Abstract}

On estimation scales ranging from $0.1 \mathrm{~nm}$ to $100 \mathrm{~nm}$, the nanoscale is part of the capacitance components of the physicalsynthetic and natural environment. Dimensionality, morphology, structure, uniformity, and agglomeration are all used to classify nanoparticles. Its functionality and effect on the environment and species are influenced by its shape and morphology. The priority research is to determine the effects of nanoparticles on any biological entity that is necessary when designing nanotechnology-based biotechnological and biomedical products. Bacteria have a remarkable ability to reduce metal ions, making them one of the most promising candidates for nanoparticle biosynthesis. Nanoparticles have been researched in the biomedical field for antimicrobial, biosensor, diagnostic imaging, and drug delivery applications. These natural technologies appear to be capable of producing stable nanoparticles with well-defined dimensions, morphologies, and compositions by optimizing reaction conditions and selecting the best bacteria. This work includes a list of the most commonly used microorganisms and associated Nanoparticles, as well as a discussion of current biotechnology and biomedical developments.

Keywords: Nanoparticle; Bacterial; Biotechnology; Biomedical Application

\section{Introduction to Nanoparticles}

Nanoscience and Nanotechnology due to its potential effects on many scientific areas such as oil, medicine, pharmaceutical industries, electronics, and space industries, has sparked a lot of interest in recent years [1]. Tiny structures and materials, ranging in size from a few nanometres to less than 100 nanometres, are the focus of this technology. Due to their high surface-to-volume ratio, nanoparticles (NPs) have distinct and substantially altered chemical, physical, and biological properties as compared to most of the same chemical composition [2]. Biosensors and catalysts, as well as optics, antimicrobial operation, device transistors, electrometers, chemical sensors, and wireless electronic logic and memory schemes, all benefit from the shape and size based properties of NPs $[3,4]$.
The nanoscale is part of the capacity components of the physical-synthetic and natural world on estimation scales ranging from $0.1 \mathrm{~nm}$ to $100 \mathrm{~nm}$ [5]. In general, as particle size decreases, the proportion of surface to volume increases, increasing the reactivity of the particles. Particles of different components exhibit extraordinary physical, compound, and natural properties at the nanoscale. NPs have a lower softening point, electrical resistivity, particular heat, diffusivity, flexibility, and mechanical quality than typical coarse-grained partners, as well as improvements in their electromagnetic and synergistic properties. With several developments, researchers are attempting to decode these NP-related properties [6].

Dimensionality, morphology, structure, uniformity, and agglomeration are all used to classify NPs. Its functionality 
and toxic impact on the environment and humans are influenced by its shape and morphology [7].

NPs are graded as one-, two-, or three-dimensional depending on their dimensionality. Thin films used in electronics and sensor applications are examples of onedimensional NPs. Carbon nanotubes, which are twodimensional NPs, have a high adsorption capacity and stability. Dendrimes and quantum dots are found in threedimensional NPs [8-10]. NPs may have a flat, circular, or crystalline structure depending on their morphology. They can also be used in single or composite form. Oxide nanoparticles, sulphides nanoparticles, and magnetic nanoparticles are the three forms of NPs [11].

The need for a comprehensive study of NPs is due to the considerable amount of scientific research, which has shown that their properties differ significantly from similar macro particles and from the substances from which they were obtained [12]. These properties depend on their composition, nature, shape, size, charge, structural features, and both the surface of the nanoparticle itself and the surface modifier molecules (if used), the preparation methods, and the process parameters [13]. There are many aspects of these biological methods that can be detected and then manipulated [14]. Nano biotechnologies, based on the use of bacteria, contribute to the reduction of NPs, have high commercial potential with the prospects of widespread use. The NPs obtained in this way show better biocompatibility due to the absence of adsorbed toxic substances. Much of the experimental research has been conducted to create diagnostic and therapeutic nanosheets [15]. Specialists of various profiles - material scientists, chemists, biologists, physicians, and veterinarians - are involved in this problem [12-16]. The purpose of these studies is to create NPs, not as a final product, but as a feedstock for biocompatible substances. Compared to conventional pathway NPs, biosynthetic NPs have some unique properties and can be used without side effects in areas such as catalysis and degradation of organic pollutants [15].

Priority research is to determine the effects of the impact of NPs on any biological entity that is required when designing biotechnology products with the involvement of nanotechnology. Such studies can only be adequate with the consistent use of biomarkers - key systemic characteristics of a living organism (biochemical, physiological, immunological, etc.) [17]. Several basic mechanisms of contact interaction of metals in different chemical forms on the model of cells of microorganisms are described [18]. The mechanism of passive deposition of metals by a bacterial cell is based on the physical and chemical binding of the structural components of the cell membrane. Metabolism-dependent cumulation of metals is associated with the functioning of cellular enzyme systems that provide metabolism and energy responses to the environment. Prokaryotic cells, due to their unique structural properties and metabolism, are able to actively interact with metals and can be a model system for studying the relationship between a cell and NPs [15].

\section{Methodologies for Synthesis of NPs using Microbes}

NPs are constantly being studied and developed [19]. Three methods are used to synthesize nanomaterials [20]. Lithography, pyrolysis, and vapor pressure are examples of physical methods. However, these strategies are very costly. Physical and chemical methods are important because they are low-productivity, energy-intensive, difficult to scale, often generate high levels of hazardous waste, and can involve the use of costly precursors [21]. Irradiation reduction, microemulsion reduction, and electrochemical reduction are also chemical methods, but chemical methods are very risky because this synthesis can also result in the presence of certain lethal chemical species adsorbed on the surface, which can have unfavourable effects in medical applications [22]. As a result, researchers have turned to biological systems for inspiration in the synthesis of NPs over the last year. Microorganisms have recently been discovered as potential environmentally friendly Nano factories, despite their numerous biotechnological applications, such as lethal metal remediation. It has been established that prokaryotes play an important role in the synthesis of NPs [23]. Adapted to their excess atmosphere and their ability to adapt to the original transmission situation, bacteria are a good selection for research [24]. The bacteria are also residual maturing, low-cost to produce, and convenient to handle. Oxygenation, incubation time, and temperature could all be easily regulated even during diffusion process. It was discovered that the $\mathrm{pH}$ of the incubation selection operation is uneven in the game of incompatible visualization and dressing NPs; nonetheless, since unconditional NP morphologies are needed for numerous technologies such as catalysts, antitumor agents, drug delivery, diagnostics, and antimicrobials, such transfer is common [22].

Bacteria are one of the best candidates for the synthesis of NPs as they have a remarkable ability to reduce heavy metal ions. Some bacterial organisms have adapted the ability to react to stresses such as the toxicity of heavy metal ions or metals by implementing complex defence mechanisms [7]. Furthermore, selected of these bacteria are capable of synthesizing inorganic materials [1]. Table 1 shows the majority of the bacterial species used in the biosynthesis of NPs, with various protocols and methodologies used among different authors and bacterial species. 


\begin{tabular}{|c|c|c|}
\hline Bacteria & Nanoparticles & Synthesis method \\
\hline Acinetobacter sp. [25] & $\mathrm{Fe}_{3} \mathrm{O}_{4}$ & Extracellular \\
\hline Acinetobacter sp. [26] & $\mathrm{Si} / \mathrm{SiO}_{2}$ & Extracellular \\
\hline Acinetobacter spp. [25] & $\mathrm{Fe}_{2} \mathrm{O}_{3}$ & Extracellular \\
\hline Aquaspirillum Magnetotacticum [27] & $\mathrm{Fe}_{3} \mathrm{O}_{4}$ & Intracellular \\
\hline Arthrobacter globiformis [28] & $\mathrm{Au}$ & Extracellular \\
\hline Arthrobacter sp. [28] & $\mathrm{Au}$ & Extracellular \\
\hline Azoarcus sp. [29] & $\mathrm{Se}$ & Intracellular \\
\hline Bacillus amyloliquefaciens [24] & $\mathrm{CdS}$ & Extracellular \\
\hline Bacillus cereus [30] & $\mathrm{Ag}$ & Extracellular \\
\hline Bacillus flexus [31] & $\mathrm{Ag}$ & Extracellular \\
\hline Bacillus licheniformis [32] & $\mathrm{Ag}$ & Intracellular \\
\hline Bacillus licheniformis [24] & $\mathrm{Ag}$ & Extracellular \\
\hline Bacillus licheniformis [33] & $\mathrm{Au}$ & Not specified \\
\hline Bacillus licheniformis [33] & $\mathrm{Ag}$ & Extracellular \\
\hline Bacillus licheniformis [33] & $\mathrm{Ag}$ & Not specified \\
\hline Bacillus licheniformis [34] & $\mathrm{Ag}$ & Extracellular \\
\hline Bacillus licheniformis [35] & $\mathrm{Ag}$ & Extracellular \\
\hline Bacillus megaterium [36] & $\mathrm{Ag}$ & Extracellular \\
\hline Bacillus methylotrophicus [24] & $\mathrm{Ag}$ & Extracellular \\
\hline Bacillus persicus [24] & $\mathrm{Ag}$ & Extracellular \\
\hline Bacillus pumilus [24] & $\mathrm{Ag}$ & Extracellular \\
\hline Bacillus sp. [37] & $\mathrm{Ag}$ & Extracellular \\
\hline Bacillus sphaericus [37, pag. 11] & $\mathrm{U}, \mathrm{Cu}, \mathrm{Pb}, \mathrm{Al}, \mathrm{Cd}$ & Extracellular \\
\hline Bacillus spp. [38] & $\mathrm{Ag}$ & Intracellular \\
\hline Bacillus subtilis [39] & $\mathrm{Au}$ & Intracellular \\
\hline Bacillus subtilis [32] & $\mathrm{Au}$ & Intracellular \\
\hline Bacillus subtilis [40] & $\mathrm{TiO} 2$ & Not specified \\
\hline Bacillus subtilis [41] & $\mathrm{Co}_{3} \mathrm{O}_{4}$ & Extracellular \\
\hline Bacillus subtilis [42] & $\mathrm{Ag}$ & Extracellular \\
\hline Bacillus subtilis [43] & $\mathrm{Ag}$ & Extracellular \\
\hline Bacillus subtilis [44] & $\mathrm{Au}$ & Intracellular \\
\hline Bhargavaea indica [24] & $\mathrm{Ag}$ and $\mathrm{Au}$ & Extracellular \\
\hline Brevibacterium frigoritolerans [24] & $\mathrm{Ag}$ & Extracellular \\
\hline Cladosporium cladosporioides [45] & $\mathrm{Ag}$ & Extracellular \\
\hline Clostridium thermoaceticum [46] & $\mathrm{CdS}$ & Extracellular \\
\hline Clostridium thermoaceticum [46] & $\mathrm{CdS}$ & Extra/Intracellular \\
\hline Corynebacterium spp. [47] & $\mathrm{Ag}$ & Intracellular \\
\hline Cupriavidus necator [32] & $\mathrm{Pd}$ & Intracellular \\
\hline
\end{tabular}




\begin{tabular}{|c|c|c|}
\hline Delftia acidovorans [48] & $\mathrm{Au}$ & Extracellular \\
\hline Desulfobacteraceae spp. [49] & $\mathrm{ZnS}$ & Not specified \\
\hline Desulfovibrio desulfuricans [32] & $\mathrm{Pd}$ & Intracellular \\
\hline Desulfovibrio desulfuricans [50] & $\mathrm{Pd}$ & Intracellular \\
\hline Desulfovibrio desulfuricans [51] & $\mathrm{Pd}$ & Extracellular \\
\hline Enterobacter cloacae [52] & $\mathrm{Ag}$ & Not specified \\
\hline Enterococcus faecium [52] & $\mathrm{Ag}$ & Extracellular \\
\hline Escherichia coli [53] & $\mathrm{Cd}$ & Intracellular \\
\hline Escherichia coli [54] & $\mathrm{Ag}$ & Not specified \\
\hline Escherichia coli [55] & $\mathrm{Cu}$ & Extracellular \\
\hline Escherichia coli [56] & $\mathrm{CdS}$ & Intracellular \\
\hline Escherichia coli [56] & $\mathrm{CdS}$ & Intracellular \\
\hline Escherichia coli [56] & $\mathrm{CdS}$ & Intracellular \\
\hline Escherichia coli [57] & $\mathrm{CdTe}$ & Extracellular \\
\hline Escherichia coli [58, pag. 5] & $\mathrm{Au}$ & Intracellular \\
\hline Escherichia coli [58] & $\mathrm{Au}$ & Intracellular \\
\hline Escherichia coli [59] & $\mathrm{Pt}$ & Not specified \\
\hline Escherichia coli [52] & $\mathrm{Ag}$ & Not specified \\
\hline Escherichia coli [43] & $\mathrm{Ag}$ & Extracellular \\
\hline Escherichia coli $[60]$ & $\mathrm{Pd}, \mathrm{Pt}$ & Extracellular \\
\hline Fusarium oxysporum [61] & $\mathrm{Ag}$ & Extracellular \\
\hline G. sulfurreducens [32] & $\mathrm{Au}$ & Extracellular \\
\hline Geobacillus sp. [62] & $\mathrm{Au}$ & Intracellular \\
\hline Geobacillus sp. [62] & $\mathrm{Au}$ & Intracellular \\
\hline Geobacter sulfurreducens [63] & $\mathrm{Pd}$ & Extracellular \\
\hline Idiomarina spp. [64] & $\mathrm{Ag}$ & Intracellular \\
\hline Klebsiella pneumoniae [65] & $\mathrm{Se}$ & Intracellular \\
\hline Klebsiella pneumoniae [65] & $\mathrm{Se}$ & Intracellular \\
\hline Klebsiella pneumoniae [66] & $\mathrm{Ag}$ & Extracellular \\
\hline Klebsiella pneumoniae [66] & $\mathrm{Ag}$ & Not specified \\
\hline Klebsiella pneumoniae [52] & $\mathrm{Ag}$ & Not specified \\
\hline Klebsiella pneumoniae [52] & $\mathrm{Ag}$ & Extracellular \\
\hline Lactobacillus acidophilus [67] & $\mathrm{Ag}$ & Extracellular \\
\hline Lactobacillus acidophilus [68] & Se & Not specified \\
\hline Lactobacillus casei [67] & $\mathrm{Ag}$ & Extracellular \\
\hline Lactobacillus crispatus [69] & $\mathrm{TiO}_{2}$ & Extracellular \\
\hline Lactobacillus mindensis [70] & Ag20 & Not specified \\
\hline Lactobacillus reuteri [67] & $\mathrm{Ag}$ & Extracellular \\
\hline Lactobacillus sp. [32] & $\mathrm{Au}, \mathrm{Ag}, \mathrm{Au}-\mathrm{Ag}$ alloys & Intracellular \\
\hline
\end{tabular}




\begin{tabular}{|c|c|c|}
\hline Lactobacillus sp. [71] & $\mathrm{TiO}_{2}$ & Extracellular \\
\hline Lactobacillus sporogens [72] & $\mathrm{ZnO}$ & Intracellular \\
\hline Lactobacillus spp. [73] & $\mathrm{Ag}$ & Extracellular \\
\hline Lactobacillus spp. [74] & $\mathrm{Au}, \mathrm{Ag}, \mathrm{Au}-\mathrm{Ag}$ & Intracellular \\
\hline Lactobacillus strains [75] & $\mathrm{Ag}$ and $\mathrm{Au}$ & Intracellular \\
\hline Lactococcus garvieae [52] & $\mathrm{Ag}$ & Extracellular \\
\hline Lysinibacillus sphaericus [76] & $\mathrm{Ag}$ & Not specified \\
\hline M. morganii [55] & $\mathrm{Cu}$ & Extracellular \\
\hline Magnetite gryphiswaldense [77] & Magnetite & Intracellular \\
\hline Magnetospirillum gryphiswaldense [78] & $\mathrm{Fe}_{3} \mathrm{O}_{4} / \mathrm{Fe}_{3} \mathrm{~S}_{4}$ & Intracellular \\
\hline Magnetotactic bacterium [79] & $\mathrm{Fe}_{3} \mathrm{O}_{4}$ & Intracellular \\
\hline Marinobacter pelagius [80] & $\mathrm{Au}$ & Not specified \\
\hline Morganella psychrotolerans [81] & $\mathrm{Ag}$ & Extracellular \\
\hline Morganella sp. [82] & $\mathrm{Cu}$ & Intracellular \\
\hline Morganella sp. [32] & $\mathrm{Ag}$ & Intracellular \\
\hline Morganella sp. [83] & $\mathrm{Ag}$ & Extracellular \\
\hline Morganella sp. [84] & Metallic $\mathrm{Cu}$ & Extracellular \\
\hline Mycobacterum psychrotolerans [55] & $\mathrm{Cu}$ & Extracellular \\
\hline Myхососcus virescens [85] & $\mathrm{Ag}$ & Extracellular \\
\hline Ochrobactrum sp. [86] & $\mathrm{Ag}$ & Extracellular \\
\hline Pantoea agglomerans [87] & $\mathrm{Se}$ & Intracellular \\
\hline Paracoccus denitrificans [32] & $\mathrm{Pd}$ & Intracellular \\
\hline Penicillium fellutanum [88] & $\mathrm{Ag}$ & Extracellular \\
\hline Planomicrobium sp. [89] & $\mathrm{TiO}_{2}$ & Extracellular \\
\hline Planomicrobium sp. [40] & $\mathrm{TiO}_{2}$ & Extracellular \\
\hline Plectonema boryanum [90] & $\mathrm{Ag}$ & Intracellular \\
\hline Plectonema boryanum [91] & $\mathrm{Au}$ & Intracellular \\
\hline Proteus mirabilis [92] & $\mathrm{Ag}$ & Extra/Intracellular \\
\hline Pseudomonas aeruginosa [32] & $\mathrm{Au}, \mathrm{Ag}, \mathrm{Pd}, \mathrm{Fe}, \mathrm{Rh}, \mathrm{Ni}, \mathrm{Ru}, \mathrm{Pt}$ & Extracellular \\
\hline Pseudomonas aeruginosa [53] & $\mathrm{Au}$ & Extracellular \\
\hline Pseudomonas aeruginosa [93] & $\mathrm{Ag}$ & Extracellular \\
\hline Pseudomonas aeruginosa [94] & $\mathrm{Se}$ & Intracellular \\
\hline Pseudomonas aeruginosa [95] & Gold & Extracellular \\
\hline Pseudomonas aeruginosa [95] & $\mathrm{Au}$ & Not specified \\
\hline Pseudomonas aeruginosa [95] & $\mathrm{Au}$ & Extracellular \\
\hline Pseudomonas aeruginosa [96] & $\mathrm{Au}$ & Extracellular \\
\hline Pseudomonas alcaliphila [97] & $\mathrm{Se}$ & Not specified \\
\hline Pseudomonas deceptionensis [24] & $\mathrm{Ag}$ & Extracellular \\
\hline Pseudomonas fluorescens [98] & $\mathrm{Cu}$ & Extracellular \\
\hline
\end{tabular}




\begin{tabular}{|c|c|c|}
\hline Pseudomonas fluorescens [99] & $\mathrm{Cu}$ & Extracellular \\
\hline Pseudomonas fluorescens [100] & $\mathrm{Au}$ & Extracellular \\
\hline Pseudomonas putida [32] & $\mathrm{Pd}$ & Intracellular \\
\hline Pseudomonas sp. [55] & $\mathrm{Cu}$ & Extracellular \\
\hline Pseudomonas sp. [101] & $\mathrm{Ag}$ & Extracellular \\
\hline Pseudomonas spp. [37] & $\mathrm{Ag}$ & Intracellular \\
\hline Pseudomonas stutzeri [32] & $\mathrm{Ag}$ & Intracellular \\
\hline Pseudomonas stutzeri [53] & $\mathrm{Ag}$ & Intracellular \\
\hline Pseudomonas stutzeri [55] & $\mathrm{Cu}$ & Extracellular \\
\hline Pseudomonas stutzeri [102] & Ag & Not specified \\
\hline Pseudomonas stutzeri [103] & $\mathrm{Ag}$ & Intracellular \\
\hline Pseudomonas stutzeri [104] & $\mathrm{Au}, \mathrm{Ag}, \mathrm{Au}-\mathrm{Ag}$ & Intracellular \\
\hline Pyrobaculum islandicum [32] & $\mathrm{Au}$ & Extracellular \\
\hline Pyrococcus furiosus [32] & $\mathrm{Au}$ & Extracellular \\
\hline Rhodococcus sp. [105] & $\mathrm{Au}$ & Intracellular \\
\hline Rhodococcus sp. [106] & $\mathrm{Au}$ & Intracellular \\
\hline Rhodococcus sp. [107] & Gold & Intracellular \\
\hline Rhodopseudomonas capsulata [32] & $\mathrm{Au}$ & Extracellular \\
\hline Rhodopseudomonas capsulata [108] & $\mathrm{Au}$ & Extracellular \\
\hline Rhodopseudomonas capsulata [109] & $\mathrm{Au}$ & Extracellular \\
\hline Rhodopseudomonas capsulata [110] & $\mathrm{Au}$ & Extracellular \\
\hline Rhodopseudomonas palustris [111] & $\mathrm{CdS}$ & Intracellular \\
\hline S. oneidensis [32] & $\mathrm{Pd}$ & Intracellular \\
\hline S. oneidensis [112] & $\mathrm{Pd}$ & Intracellular \\
\hline Salmonella typhirium [113] & $\mathrm{Ag}$ & Extracellular \\
\hline Shewanella algae [114] & $\mathrm{Au}, \mathrm{Pt}$ & Intracellular \\
\hline Shewanella algae [115] & $\mathrm{Au}$ & Extra/Intracellular \\
\hline Shewanella algae [91] & $\mathrm{Au}$ & Intracellular \\
\hline Shewanella oneidensis [116] & $\mathrm{UO}_{2}$ & Extracellular \\
\hline Shewanella oneidensis [116] & $\mathrm{U}(\mathrm{IV})$ & Extracellular \\
\hline Shewanella sp. [117] & AsS & Extracellular \\
\hline Staphylococcus aureus [118] & $\mathrm{Ag}$ & Extracellular \\
\hline Stenotrophomonas maltophilia [119] & $\mathrm{Au}$ & Intracellular \\
\hline Stereum hirsutum [120] & $\mathrm{Cu}, \mathrm{CuO}$ & Extracellular \\
\hline Streptomyces sp. [121] & $\mathrm{Ag}$ & Extracellular \\
\hline Streptomyces sp. [55] & $\mathrm{Cu}$ & Extracellular \\
\hline Streptomyces sp. [122] & Mn and $\mathrm{Zn}$ & Intracellular \\
\hline Streptomyces sp. [123] & $\mathrm{Ag}$ & Extracellular \\
\hline Streptomyces sp. [124] & $\mathrm{Ag}$ & Extracellular \\
\hline
\end{tabular}




\begin{tabular}{|c|c|c|}
\hline Streptomyces spp. [125] & $\mathrm{Ag}$ & Extracellular \\
\hline Thermoanaerobacter $s p .[126]$ & $\mathrm{Cu}$ & Extracellular \\
\hline Thermomonospora sp. [106] & $\mathrm{Gold}$ & Extracellular \\
\hline Thermomonospora $s p .[106]$ & $\mathrm{Au}$ & Extracellular \\
\hline Thermomonospora sp. [106] & $\mathrm{Au}$ & Extracellular \\
\hline Thermomonospora sp. [127] & $\mathrm{Au}$ & Not specified \\
\hline Thiobacillus thioparus [128] & $\mathrm{Fe}_{2} \mathrm{O}_{3}$ & Extracellular \\
\hline Trichoderma viride [129] & $\mathrm{Ag}$ & Extra/Intracellular \\
\hline Verticillium luteoalbum [130] & $\mathrm{Au}$ & Intracellular \\
\hline Weissella oryzaecastro [24] & $\mathrm{Ag}$ & . \\
\hline
\end{tabular}

Table 1: The table reports the biosynthesis of NP from different microbial candidates, according to the method and procedures found in the literature.

\section{The Biological Synthesis of Nanoparticles}

NPs biosynthesis is carried out by culturing microorganisms in specific nutrient media containing the corresponding ions. Depending on the localization site, the synthesis of NPs by microorganisms, in particular bacteria, is classified into intracellular and extracellular [131]. Metal ions enter the bacterial cell through ion channels, through active transport, endocytosis, or penetration through the lipid membrane [132]. The process of intracellular synthesis involves the process of trapping, bio reduction, and capping of various NPs [133]. Extracellular synthesis consists of enzyme secretion, bio reduction and particle capping [10]. Most published reports [15] have argued that extracellular nanoparticle synthesis is preferable because low-flow and purification processes are easier compared to intracellular methods. Most published works [134] argue that extracellular nanoparticle synthesis is preferable because downstream and purification processes are easier than intracellular methods. The enzyme nitrate reductase is one of the most widely used enzymes, and it is believed to be involved for the synthesis of NPs such silver and gold NPs. Individual enzymes play an important role in the transport of electrons from donors to the positive metal ion during in the bio reduction process [135].

\section{Extracellular Mechanism}

As for extracellular biosynthesis, a general scheme can be followed. Due to the production of the extracellular reductase enzyme in the cell-free supernatant, enzymatic bio-reduction of metal ions occurs within the cell-free supernatant with the end result of NP formation within a cell-free supernatant. The test strain is grown in appropriate media and incubated at $37{ }^{\circ} \mathrm{C}$ on an orbital shaker at $150 \mathrm{rpm}$. The broth is centrifuged after incubation, and the supernatant is used to create NPs. The supernatant is transferred to separate reaction vessels containing appropriate concentrations of metal ions and incubated for 72 hours [136]. The presence of NPs in the solution is indicated by a color shift in the reaction mixture, and the bio reduction of silver ions in the solution is controlled by sampling the aqueous solution and measuring the absorption spectrum with a UV-visible spectrophotometer. Silver's morphology and uniformity [137].

\section{Intracellular Mechanism}

As far as intracellular biosynthesis is concerned, the mechanism is different from the previous one, but it is always possible to follow a general scheme. Given the intracellular mechanism, an entrapment of positively charged metal ions occurs within the negatively charged cell wall, subsequently an enzymatic bio-reduction of the metal ions occurs within the cell wall with formation of nanoclusters and, as a final step, the NPs are widespread in the cell wall. The culture is grown in appropriate liquid media and incubated at the proper temperature on a shaker. The flask is held at a static temperature after incubation to enable the biomass to settle, after which the supernatant is discarded and sterile distilled water is added to wash the cells [137]. The flask is held at room temperature for 30 minutes to settle the biomass, after which the supernatant is discarded once more. The biomass is then centrifuged for 10 minutes to isolate it from the sterile distilled water. Wet biomass is exposed to $50 \mathrm{~mL}$ of sterilized aqueous metals solution at different dilutions and incubated on shaker at appropriate temperature until visual color change is detected. Silver NPs are formed when the color changes from pale yellow to brownish, gold NPs are formed when the color changes from pale yellow to pinkish, and manganese and zinc NPs are formed when the color changes from whitish yellow to yellow [138]. In summary, extracellular NP synthesis involves trapping metal ions on the cell surface and reducing them in the presence 
of enzymes, while intracellular NP synthesis involves carrying metal ions into the microbial cell and creating NPs in the presence of enzymes [28]. Drug carriers for targeted delivery, cancer treatment, gene therapy and DNA analysis, antibacterial agents, biosensors, separation science, and magnetic resonance imaging have all allowed use of the biosynthesized NPs [139-141].

\section{Learning, Issues, and Possibilities for Large- Scale Applicability}

In vivo microbial nano biosynthesis, as well as the ability to track and adjust nanomaterial properties, pose a concrete potential for future growth and applications in biosensorics and biomedical fields [142]. Bacteria have shown the ability to synthesize nanomaterials both extracellularly and intracellularly. In terms of metal NP dispersity and purification, these mechanisms typically produce opposite advantages and disadvantages [143]. Extracellularly produced NPs are more polydisperse (having a wide range of sizes) than intracellularly

produced NPs. Extracellular nanomaterial processing, on the other hand, necessitates less downstream extraction/ purification steps (e.g., ultrasound treatment and detergent use) [144]. As a result, the extracellular mediated synthesis mentioned for yeast and molds can greatly simplify purification steps while also allowing microorganisms to be reused for additional biosynthesis cycles [145]. However, the characterization and identification of the enzymes responsible for nano biosynthesis in molds is still uncomplete [146]. Carbon dioxide (as a carbon source), light (as an energy source), inorganic nutrients, and water are all used in the photoautotrophic metabolism of microalgae and cyanobacteria. This condition lowers the cost of culture media (when compared to culture media used for the growth of bacteria, yeasts, and molds) and can help drive potential scaling-up from the laboratory to the industrial scale, including through the design and production of solar photobioreactors for the fixation (and reduction) of atmospheric $\mathrm{CO}_{2}[142]$.

\section{Cell Culture Conditions for the Synthesis of Nanoparticles}

To avoid limiting the applications of microbial biosynthetic nanomaterials, the costs of culture media for microbial growth should be seriously considered for potential large-scale productions. Bacterial nanocellulose is one current example, whose applications are still limited to a few biomedical devices, owing to the high cost of culture medium [142,147]. Furthermore, for monitoring, tuning, and improving the characteristics of microbial biosynthesized nanomaterials, optimization and standardization of microbial cell culture growth protocols and modifications to culture conditions are critical. The impact of physicchemical parameters in cell culture operational setup on nanomaterials biosynthesis has previously been discussed. I microbial cell concentration; (ii) precursor concentration; (iii) $\mathrm{pH}$; and (iv) temperature are some of these variables. The optimal $\mathrm{pH}$, temperature, and $\mathrm{NaCl}$ concentration for achieving high purity and high synthesis rate of cadmium selenide NPs by the bacterium Pseudomonas aeruginosa strain RB have been investigated. Surprisingly, the results of this study revealed that the best conditions for NP synthesis did not correspond to the best conditions for Pseudomonas aeruginosa strain RB development [148]. For the bacterium E. coli strain DH5, the effects of precursor concentration, temperature, and $\mathrm{pH}$ on silver nanoparticle synthesis and particle sizes have been identified [149]. Other recent examples include: I the temperature dependence of the size and monodispersed of silver NPs biosynthesis by the mold Trichoderma viride; and (ii) the temperature dependence of the size and monodispersed of silver NPs biosynthesis by the mold Trichoderma viride [150], (ii) the effect of yeast on the form and scale of gold nanostructures synthetized Yarrowia lipolytica strain NCIM 3589 by altering the proportion of cell concentration to precursor gold salt concentration, (ii) the effect of temperature on gold nanostructures release from the cell wall into the aqueous phase, and regulation of bacterial growth kinetics of Morganella psychrobacterium $[81,142,151]$. These results have been ascribed to the activation of enzyme (s) involved in biosynthetic pathway $[142,152]$. The optimization of frustule morphological properties (e.g., pore sizes and pore density) has been explored by adjusting operational parameters of the experimental setup (e.g., $\mathrm{pH}$, salinity, temperature, nutrient concentration, precursor $\mathrm{Si}(\mathrm{OH}) 4$ concentration, and light regime), despite the fact that controlling the biomineralization process remains a challenge [153]. Researchers discovered that when Coscinodiscus wailesii frustules were exposed to sublethal nickel concentrations, their pore sizes changed [142]. It was recently reported that frustules or other biomineralized structures can be chemically modified in vivo. By adding given precursors to the culture medium at sublethal concentrations, these in vivo chemical modifications result in inorganic elements/ compounds doping of biomineralized structures. Pinnularia sp. frustules or diatoms have been doped in some studies. Frustules of Thalassiosira weissflogii with titania $\left(\mathrm{TiO}_{2}\right)$ [154] by attaching $\mathrm{Ge}(\mathrm{OH})_{4}$ or $\mathrm{GeO}_{2}$ to the diatom culture medium at photobioreactor scale-productions, nano biosynthesis containing $\mathrm{Si}-\mathrm{Ge}$ oxides nano comb in diatom Nitzschia and Pinnularia sp. [142]. In comparison to diatoms, the calcareous-based shell of marine protozoa foraminifera has not been thoroughly investigated for nanotechnological applications. The inclusion of fluorescent magnetite NPs within the calcite skeletal structure of the unicellular 
organism foraminifer Amphistrigina lesson resulted in the in vivo preparation of a bionic material. The natural biomineralization mechanism of growth in the presence of magnetic NPs functionalized with a hydroxylated dextran shell was exploited in this in vitro synthetic approach [142].

\section{Application of Bacterial NPs}

In the biomedical field, NPs have been studied for antimicrobial, biosensing, imaging and drug delivery applications [155]. Overall, some researchers are interested in NPs because their syntheses are less harmful to the environment, bacteria produce more evenly distributed NPs, and some of them can be easily biodegradable. Despite the fact that a number of studies have been performed on the use of NPs [156]. The emergence of drug-resistant bacteria and the rising incidence of hospital infection outbreaks has sparked renewed interest in NPs. NPs have been widely used in many fields due to their excellent antimicrobial resistance properties [157]. Each form of NP has its own collection of advantages and distribution patterns. Factors including average particle size, shape, specific surface area, and surface curvature affect behaviour and antibacterial mechanism. In reality, the use of nanoparticles in the fight against bacteria has resulted in a decrease in bacterial infection [158].

\section{Antimicrobial uses of Biosynthesized Nanomaterials in Medicine}

The emergence of antibiotic-resistant pathogenic strains has resulted in an increment in the amount of infectious diseases linked to these bacteria. Microbes develop resistance to antibiotics after being exposed to them repeatedly for several generations [159]. To resist antibiotics, they have evolved complex resistance mechanisms such as inactivation, alteration of the target site, and metabolic pathway transformation [160]. As a result, due to a lack of time, alternative antibiotics with strong bactericidal and bacteriostatic activities are requested. Microbial NPs have been discovered to have potent antibacterial properties. NPs' performance is likely due to their wider surface area, which allows for better contact with microorganisms. NPs stick to the cell membrane and then enter the cell by communicating with DNA, disrupting the replication process or attacking pathogens' respiratory chains. Pathogenic bacteria such as Salmonella typhi, Escherichia coli, Klebsiella pneumonia, Staphylococcus aureus, and Pseudomonas aeruginosa were found to have a similar bactericidal function as silver NPs obtained from the endophytic bacterium Bacillus cereus [161]. Another mechanism of NP antimicrobial activity is structural damage to cellular membranes caused by the forming of pits, which is accompanied by the degradation of cellular components and finally death [162]. Furthermore, when NPs are used in conjunction with traditional antibiotics, their antimicrobial efficacy can be increased by a factor of ten. Antibiotics including certain nitrofurantoin, carbenicillin, and ciprofloxacin are shown to have a synergistic effect with AgNPs expressed by R. stolonifer against ESBL-strains of Enterobacteriaceae. Carbenicillin and ciprofloxacin saw 33.56 percent and 30.53 percent increases, respectively, while nitrofurantoin showed a 50 percent rise [159]. In another study, the antibiotics vancomycin, penicillin G, lincomycin, novobiocin, rifampicin, and oleandomycin were found to be more effective against pathogenic strains of Vibrio parahaemolyticus, Bacillus cereus, Salmonella enterica, Escherichia coli, Bacillus anthracis, and Candida albicans when combined with silver NPs provided by Brevibacterium frigorito [10]. Despite the fact that several studies have revealed the antimicrobial ability of AgNPs generated by microbes, only a few studies have recorded antimicrobial activities of substances other than AgNPs. Additionally, the biosynthesis of titanium oxide NPs from Planomicrobium sp. was confirmed and identified, as well as their extensive antimicrobial activity against B. Subtilis, K. planticola, and A. niger. Antimicrobial properties of iron NPs produced by Fusarium oxysporum against Bacillus, E. coli, and Staphylococcus sps. The respiration process of pathogenic microorganisms was disrupted by small iron NPs that reduced oxygen supply [142]. Biosynthesized silver NPs have well-known antimicrobial properties against pathogenic microorganisms [142,159]. Other biologically synthesized NPs' antimicrobial activities and mechanisms of action, on the other hand, have yet to be identified.

\section{Antitumor and Anticancer Properties of NPs}

In recent years, cancer has been one of the leading causes of death all over the world. Cancer illnesses are a category of diseases characterized by uncontrollable growth of growth cells and delayed or absent apoptosis. Radiation, chemotherapy, and surgery are all traditional cancer treatments that have side effects [159]. Furthermore, early diagnostics and localized drug delivery to a specific organ are still in their infancy [163]. As a result of these limitations, the prevalence of different forms of cancers is increasing by the day. As a result, it is important to seek out logical solutions in order to solve these problems. Nanomedicine has been used to successfully detect tumors, administer targeted drugs, and treat them $[134,163]$. Because of their inherent advantages, biosynthesized NPs have the ability to promote molecular interactions and cross biological boundaries without harming healthy cells. Researchers tested the anticancer properties of platinum NPs made by Saccharomyces boulardii against A431 and MCF-7 cell lines in vitro. Breast cancer is one of the leading causes of death in women. Silver nanoparticles derived from Cryptococcus laurentii were found to have antitumor activity in both normal and cancer cell lines. Apoptosis, viability, and endocytic activity of cancer 
cell lines were all affected by biosynthesized AgNPs [159]. Besides, efficacy of AgNPs was found to be proportional to endocytosis activity of cancer cells [159]. Selenium is a trace material with cancer-fighting properties. The anticancer properties of selenium nanorods (SeNrs) derived from Streptomyces bikiniensis were discovered in MCF-7 and Hep-G2 human cancer cells. The anticancer activity of these compounds was thought to be due to the mobilization of chromatin-bound copper, followed by pro-oxidant action, and the death of HepG2 and MCF-7 cells [105]. In another study, gold NPs developed by Streptomyces cyaneus were tested in vitro against human liver and breast carcinoma cells, HEPG-2 and MCF-7, respectively, for anticancer activity. AuNPs mediated cytokinesis detention, induced mitochondrial apoptosis, localized nuclei of cells, causing DNA impairment, and stimulated mitochondrial apoptosis [164]. Biologically synthesized NPs have been shown to have anticancer activity in vitro in a number of studies, but their commercialization remains a mystery. Furthermore, defining toxicity and immune response prior to their use for diagnostic and treatment purposes is crucial.

\section{In Drug Delivery Systems, NPs are used to Transport Drugs}

Targeted drug delivery, drug bioavailability, bioactivity, and stability have all been found to be more efficient with NPs. Water-soluble polymers, such as natural antibodies and synthetic polymers, nanospheres of natural or synthetic polymers, liposomes consisting of vesicles with bilayer walls, polymeric micelles, and emulsions stabilized by amphipathic surface coatings are examples of drug delivery nano-vehicles [159]. The surface properties and small size of NPs help pharmacologically active compounds penetrate all of the human body's cellular compartments at the fastest possible time. When drugs form conjugates with NPs by encapsulation or different linker molecules, toxicity can be regulated. They help patients by reducing the toxic side effects of drug carrier systems while maintaining therapeutic effects. Unique targeting and biodistribution, biocompatibility, and protection are all advantages of NPs over traditional drug delivery systems [165]. Biosynthesized ZnO NPs loaded with anthraquinone by Rhodococcus pyridinivorans demonstrated concentration-dependent cytotoxicity against HT-29 colon carcinoma cells in a dose-dependent manner, suggesting that they could be used as an anticancer drug delivery vehicle [166]. Hydrophilic NPs have the potential to improve drug absorption and diffusion within cells. The anticancer drug doxorubicin was conjugated to multi-shaped gold NPs extracted from the fungus Helminthosporum solani. The conjugated drug was taken into HEK293 cells more easily and had cytotoxicity equivalent to doxorubicin. [167]. Another research used gadolinium oxide nanoparticles made by the thermophilic fungus Humicola sp. to bioconjugate with the anticancer drug Taxol to improve its effectiveness against antitumor cells [159]. Similarly, Humicola-derived gold NPs conjugated with doxorubicin have been used in hepatic cancer care as a targeted drug delivery system [168]. Biogenic nanocrystals have been revealed to be promising drug delivery vehicles, but their toxicity to other cellular compartments and biocompatibility must be assessed first.

\section{In The Field of Diagnosis}

Infectious disease prevalence is one of the leading causes of morbidity and mortality in developing countries [159]. Though infectious diseases begin in a small area, they can rapidly spread from one region to another, leading to a global pandemic. Rapid disease detection necessitates the use of cutting-edge diagnostic technology [9]. Culturing microorganisms, microscopy, biochemical experiments, immunoassays, and molecular diagnostics are all traditional methods of disease detection and diagnosis. Nonetheless, these approaches are inconvenient, time-consuming, and exhausting. Nanomaterials include pathogen detection tools that are fast, precise, reliable, easy to use, and ultrasensitive. Metallic nanoparticles, fluorescent nanoparticles (quantum dots and dye-loaded NPs), and magnetic nanoparticles have all been successfully used to photograph, monitor, and classify a variety of pathogens [141]. The role of biosynthesized nanomaterials in diagnostics, on the other hand, is poorly understood. The ability of Candida albicans-mediated biosynthesized gold nanoparticles to probe liver cancer cells by binding with liver cancer cell surface-specific antibodies was investigated in a study. The antibody-conjugated gold particles bind specifically to the surface antigens of affected cells, allowing them to differentiate between normal and cancer cells without a doubt [9]. The use of microbially synthesized nanomaterials in diagnostics is still in its early stages, and further progress in this area will provide a more viable future prospect.

\section{Conclusion}

Specific resistance mechanisms, such as efflux pumps, metal efflux systems, metal inactivation and complexation, metal permeability and the lack of specific metal transport systems, alteration of solubility and toxicity by changes in the redox state of metal ions, and extracellular precipitation of metals, can help bacteria survive and develop in stressful situations and volatilization of toxic metals by enzymatic reactions [1]. The stability and aggregation of biosynthesized NPs, crystal growth control, form, scale, and size distribution are the most significant problems encountered with biobased approaches. Furthermore, biologically synthesized NPs are more polydisperse than chemically synthesized NPs. Important parameters that regulate organism development, cellular activities, and enzymatic processes can be optimized 
to control the properties of NPs [15,152]. As a result, more detailed research is needed to understand the exact reaction mechanisms and identify the enzymes and proteins involved in the biosynthesis of NPs. The use of bacteria to synthesize NP on a large scale is appealing because it eliminates the need for dangerous, harmful, and costly chemical materials in the synthesis and stabilization processes. These natural technologies appear to be capable of producing stable NPs with well-defined sizes, morphologies, and compositions by optimizing reaction conditions and selecting the best bacteria $[1,22]$. The most significant drawbacks of bacteriabased NP biosynthesis are the time-consuming purification steps and a lack of knowledge of the mechanisms. Controlling the shape and size of the particles, as well as achieving monodispersity in the solution process, are two of the most common challenges in NP biosynthesis [1]. Before this biological approach becomes a viable and competitive alternative for the industrial synthesis of NP, it appears that many significant technological challenges must be addressed. Increasing the scale of manufacturing at the production level is one of the most difficult challenges. Furthermore, little is known about the mechanistic aspects of NP biosynthesis, and knowledge of these aspects is needed for the efficient and logical production of NP biosynthesis. The following are some of the important factors to consider in a well-defined NP production process:

- Collection of the greatest bacteria: The researchers focused on some essential intrinsic properties of the bacteria, such as growth rate, enzymatic activities, and biochemical pathways, in order to choose the best candidates. The selection of a good candidate for nanoparticle development should be based on the application for which the NPs will be used. It may be necessary, for example, to synthesize NP in smaller sizes or with complex forms, or it may be necessary to synthesize NP in a shorter amount of time.

- Range of the biocatalyst state: Biocatalysts, which can be whole cells, crude enzymes, or distilled enzymes, are the key agents in the synthesis of NPs. It appears that using the cell's culture supernatant or cell extract will speed up the reaction. These NPs, on the other hand, did not demonstrate long-term stability. Furthermore, in the case of intracellular derived NPs, the release of NP from cells was a significant aspect that could be calculated. The majority of the responses responsible for NP synthesis tend to be bio-reductions. We need stoichiometric amounts of coenzymes (e.g., NADH, NADPH, FAD, etc.) in bio reduction processes. Since whole cells are more costly, they are favored because the coenzymes can be recycled in the pathways into live whole cells.

The conditions are ideal for cell growth and enzyme activity. Larger quantities of enzymes are needed, which can be found by synthesizing more biomass. As a result, optimizing the rising conditions is extremely important. It is essential to optimize nutrients, inoculum size, $\mathrm{pH}$, light, temperature, buffer power, and mixing speed. Induction of the responsible enzymes appears to be essential as well. Subtoxic levels of substrates or associated mixtures present from the start of growth will boost activity. When using whole cells and raw enzymes, the harvest time is crucial. Then, as the organism grows, enzyme activity can need to be regulated.

- Finest reaction environments: Harvesting the cells to eliminate unnecessary residual nutrients and metabolites to prevent harmful reactions and provide a safer means of analysis is ideal. Yield and speed of development are critical factors to consider when using bacteria to synthesize NPs on a large scale. Then, in the reaction mixture, we must optimize the bio reduction conditions. The substrate concentration, biocatalyst concentration, electron donor concentration, exposure time, $\mathrm{pH}$, temperature, buffer power, mixing speed, and light must all be optimized. Complementary factors such as visible light or microwave irradiation, as well as boiling, were used to influence the morphology, duration, and rate of the reaction. Highly stable NPs with ideal dimensions and morphologies tend to be obtained by optimizing these essential parameters. Furthermore, the purification, isolation, and stabilization of the NPs generated are critical, and challenges must be overcome in this region. Researchers concentrated their efforts on identifying the best reaction conditions and cellular pathways involved in metal ion bioreduction and NP synthesis.

- Extraction and purification procedures: The extraction and purification of metal NPs developed by bacteria for future applications has not been well studied, but research is underway to determine the best methods. Additional processing steps, such as ultrasonic treatment or reaction with suitable detergents, are needed to release the intracellularly formed NPs. The recovery of precious metals from mining waste and metal leachate may be hampered by this. Biomatrix metallic NPs have the potential to serve as catalysts in a variety of chemical reactions. This will make it easier to keep NPs in bioreactors. To extract NPs produced by cells, physic-chemical methods such as freeze-thaw, heating processes, and osmotic shock can be used. However, it appears that these methods will disrupt the structure of NPs, resulting in accumulation, precipitation, and sedimentation. This can alter the shape and size of NPs as well as interfere with their proper properties. Enzymatic lysis of intracellular NP-containing microbial cells can also be used, but this process is costly and unsuitable 
for large-scale industrial NP production. Surfactants and organic solvents appear to be viable options for NP extraction and stabilization, but these chemicals are toxic, costly, and risky. It should be noted that in the case of extracellular NP development, the centrifuge can be used to extract and purify the NPs, but aggregation can occur.

- Maintenance of the formed NPs: Even after many weeks at room temperature, the NPs provided by these biocompatible methods maintained an interesting permanency without aggregation. The microorganisms' secreted proteins and enzymes may be responsible for the NPs' stability. As a result, it appears that these environmentally friendly methods can be used to make highly stable NPs.

The laboratory technique is being scaled up to an industrial scale. Improved NP biosynthesis can be achieved by optimizing reaction conditions. When considering critical aspects such as types of organisms, hereditary and genetic properties of organisms, optimal conditions for cell growth and enzymatic activity, optimal reaction conditions, and selection of the biocatalyst, biological protocols could be used for highly stable and well characterized NP synthesis. Changing the reaction conditions above can be used to determine the size and morphology of the NPs. Crop culture, seed inoculation into biomass, cell harvesting, NPs synthesis by adding metal ions to cells, cell separation by filtration, cell homogenization to separate NPs products, NPs stabilization, product formulation, and quality control are all steps in the industrial-scale synthesis of metal NPs using biomass.

\section{References}

1. Iravani S (2014) Bacteria in Nanoparticle Synthesis: Current Status and Future Prospects. International Scholarly Research Notices 2014: 359316.

2. Moshfegh AZ (2009) Nanoparticle catalysts. J Phys D Appl Phys 42(23): 233001.

3. Bhattacharya D, Gupta RK (2005) Nanotechnology and Potential of Microorganisms. Critical Reviews in Biotechnology 25(4): 199-204.

4. Paull R, Wolfe J, Hébert P, Sinkula M (2003) Investing in nanotechnology. Nature Biotechnology 21(10): $1147-$ 1147.

5. Montes Burgo I,WalczykD, Hole P(2021) Characterisation of nanoparticle size and state prior to nanotoxicological studies. Springer 12: 47-53.

6. Luksiene Z (2017) 16-Nanoparticles and their potential application as antimicrobials in the food industry. Food preventions pp: 567-601.

7. Buzea C, Pacheco II, Robbie K (2007) Nanomaterials and nanoparticles: sources and toxicity. Biointerphases 2(4): 17-71.

8. Pal S, Jana U, Manna P, Mohanta G, Manavalan R (2011) Nanoparticle: An overview of preparation and characterization. Journal of Applied Pharmaceutical Science 1: 228-234.

9. Hauck T, Anderson R, Fischer H, Newbigging $\mathrm{S}$, Chan $\mathrm{W}$ (2010) In vivo Quantum-Dot Toxicity Assessment. 6(1): $138-144$

10. Chaturvedi Vk, Singh A, Singh VK, Singh MP (2019) Cancer Nanotechnology: A New Revolution for Cancer Diagnosis and Therapy. Current Drug Metabolism 20(6): 416-429.

11. Litti L, Reguera J, de Abajo FJG, Meneghetti M, Liz Marzán LM (2020) Manipulating chemistry through nanoparticle morphology. Nanoscale Horizons 5(1): 102-108.

12. Nasrollahzadeh M, Sajadi SM, Sajjadi M, Issaabadi Z (2019) An Introduction to Nanotechnology. An Interface Science and Technology pp: 1-27.

13. Targeting microRNAs using nanotechnology in pulmonary diseases - Panminerva Medica 2018 December 60(4): 230-201.

14. Dhapte V, Pokharkar V (2019) Nanosystems for drug delivery: Design, engineering, and applications. pp: 321345 .

15. Tsekhmistrenko SI, Bityutskyy VS, Tsekhmistrenko OS, Horalskyi LP, Tymoshok NO, et al. (2020) Bacterial synthesis of nanoparticles: A green approach. Biosys divers 28(1): 9-17.

16. Prasad R, Thirugnanasanbandham K (2019) Advanced Research in Nanosciences for Water Technology. Springer International Publishing.

17. (2021) The Effect of Nanoparticle Size, Shape, and Surface Chemistry on Biological Systems. Annual Review of Biomedical Engineering.

18. Carnes CL, Klabunde KJ (2003) The catalytic methanol synthesis over nanoparticle metal oxide catalysts. Journal of Molecular Catalysis A Chemical 194(1): 227236.

19. Iskandar F (2009) Nanoparticle processing for optical applications - A review. Advanced Powder Technology 
20(4): 283-292.

20. Misra SB (2021) The complexity of nanoparticle dissolution and its importance in nanotoxicological studies. Science Direct 438(1): 225-232.

21. Kroll A, Pillukat HM, Hahn D, Schnekenburger J (2009) Current in vitro methods in nanoparticle risk assessment: Limitations and challenges. European Journal of Pharmaceutics and Biopharmaceutics 72(2): 370-377.

22. Arshad A (2017) Bacterial Synthesis and Applications of Nanoparticles pp: 30.

23. Li X, Xu H, Chen ZS, Chen G (2021) Biosynthesis of Nanoparticles by Microorganisms and Their Applications. Journal of Nanomaterials 2011.

24. Singh P, Kim YK, Zhang D, Yang DC (2016) Biological Synthesis of Nanoparticles from Plants and Microorganisms. Trends in Biotechnology 34(7): 588599.

25. Bharde A (2005) Bacterial Aerobic Synthesis of Nanocrystalline Magnetite. Journal of the American Chemical Society 127(26): 9326-9327.

26. Singh (2008) Bacterial synthesis of silicon/silica nanocomposites. Journal of Materials Chemistry RSC Publishing pp: 22.

27. Fe sub 3 _sub 0 sub 4 _sub and Fe sub 3 _sub $S$ sub 4 _sub in a.pdf».

28. Kalabegishvili Tl (2012) Synthesis of gold nanoparticles by some strains of Arthrobacter genera. Journal of Materials Science and Engineering 2.

29. Fernández Llamosas H, Castro L, Blázquez ML, Díaz E, Carmona M (2016) Biosynthesis of selenium nanoparticles by Azoarcus sp. Microbial Cell Factories 15(1): 109.

30. Prakash A, Sharma S, Ahmad N, Ghosh A, Sinha P (2011) Synthesis of Agnps By Bacillus Cereus Bacteria and Their Antimicrobial Potential. Journal of Biomaterials and Nanobiotechnology 2(2): 11.

31. Priyadarshini S, Gopinath V, Meera Priyadharsshini N, Mubarak Ali D, Velusamy P (2013) Synthesis of anisotropic silver nanoparticles using novel strain, Bacillus flexus and its biomedical application. Colloids and Surfaces B Biointerfaces 102: 232-237.

32. Castro L, Blázquez ML, Angel Muñoz A, González FG, Ballester A (2014) Mechanism and Applications of
Metal Nanoparticles Prepared by Bio-Mediated Process, Reviews in Advanced Sciences and Engineering 3(3): 199-216.

33. Kalishwaralal K, Deepak V, Kumar Pandian SR, Gurunathan S (2009) Biological synthesis of gold nanocubes from Bacillus licheniformis. Bioresource Technology 100(21): 5356-5358.

34. Kalimuthu K, Suresh Babu R, Venkataraman D, Bilal M, Gurunathan S (2008) Biosynthesis of silver nanocrystals by Bacillus licheniformis. Colloids and Surfaces B: Biointerfaces 65(1): 150-153.

35. Shivaji S, Madhu S, Singh S (2011) Extracellular synthesis of antibacterial silver nanoparticles using psychrophilic bacteria. Process Biochemistry 46(9): 1800-1807.

36. Saravanan M, Vemu AK, Barik SK (2011) Rapid biosynthesis of silver nanoparticles from Bacillus megaterium (NCIM 2326) and their antibacterial activity on multi drug resistant clinical pathogens. Colloids and Surfaces B Biointerfaces 88(1): 325-331.

37. Das VL, Thomas R, Soniya EV (2014) Extracellular synthesis of silver nanoparticles by the Bacillus strain CS 11 isolated from industrialized area. Springer 4:121126.

38. Pugazhenthiran P (2009) Microbial synthesis of silver nanoparticles by Bacillus sp. Springer 11: 1811.

39. Southam G, Beveridge TJ (1996) The occurrence of sulfur and phosphorus within bacterially derived crystalline and pseudocrystalline octahedral gold formed in vitro. Geochimica et Cosmochimica Acta 60(22): 4369-4376.

40. Kirthi AV (2011) Biosynthesis of titanium dioxide nanoparticles using bacterium Bacillus subtilis. Materials Letters 65(17): 2745-2747.

41. Shim HW (2021) Highly Reversible Lithium Storage in Bacillus subtilis-Directed Porous Co304 Nanostructures. ACS Nano 5(1): 443-449.

42. Saifuddin N, Wong CW, Yasumira AAN (2009) Rapid Biosynthesis of Silver Nanoparticles Using Culture Supernatant of Bacteria with Microwave Irradiation. E-Journal of Chemistry pp: 6.

43. El- Raheem A (2011) Extracellular Biosynthesis of Silver Nanoparticles Using Escherichia coli ATCC 8739, Bacillus subtilis ATCC 6633, and Streptococcus thermophilus ESh1 and Their Antimicrobial Activities.

44. Beveridge TJ, Murray RG (1980) Sites of metal deposition in the cell wall of Bacillus subtilis. Journal of Bacteriology 
141(2).

45. Balaji DS, Basavaraja S, Deshpande R, Mahesh DB, Prabhakar BK, et al. (2009) Extracellular biosynthesis of functionalized silver nanoparticles by strains of Cladosporium cladosporioides fungus. Colloids and Surfaces B: Biointerfaces 68(1): 88-92.

46. Cunningham DP, Lundie LL (2021) Precipitation of cadmium by Clostridium thermoaceticum. Applied and Environmental Microbiology pp: 7-14.

47. Bai HJ (2021) Biological Synthesis of Semiconductor Zinc Sulfide Nanoparticles by Immobilized Rhodobacter sphaeroides 28: 1135-1139.

48. Wyatt MA (2014) Gold nanoparticle formation via microbial metallophore chemistries. pp: 16.

49. Labrenz M (2021) Formation of Sphalerite (ZnS) Deposits in Natural Biofilms of Sulfate-Reducing Bacteria. Science 290(5490): 1744-1747.

50. Gomez Bolivar J, Mikheenko IP, Macaskie LE, Merroun ML (2019) Characterization of Palladium Nanoparticles Produced by Healthy and Microwave-Injured Cells of Desulfovibrio desulfuricans and Escherichia coli. Nanomaterials 9(6): 857.

51. Cei J (2021) Nanoporous Cellulose as Metal Nanoparticles Support. Biomacromolecules 10: 87-94.

52. Shahverdi AR, Minaeian S, Shahverdi HR, Jamalifar H, Nohi AA (2007) Rapid synthesis of silver nanoparticles using culture supernatants of Enterobacteria: A novel biological approach. Process Biochemistry 42(5): 919923.

53. Shah M, Fawcett D, Sharma S, Tripathy SK, Poinern GEJ (2015) Green Synthesis of Metallic Nanoparticles via Biological Entities. Materials 8(11): 7278-7308

54. Rathod D (2016) A new report of Nocardiopsis valliformis strain 0T1 from alkaline Lonar crater of India and its use in synthesis of silver nanoparticles with special reference to evaluation of antibacterial activity and cytotoxicity. 205: 435-447.

55. Moses V (2014) Biological Synthesis of Copper Nanoparticles and its impact -a Review. Ago.

56. Sweeney RY (2004) Bacterial Biosynthesis of Cadmium Sulfide Nanocrystals. Chemistry \& Biology 11(11): 1553-1559.

57. Bao H (2010) Extracellular microbial synthesis of biocompatible CdTe quantum dots», Acta Biomaterialia
6(9): 3534-3541.

58. Du L, Jiang H, Liu X, Wang E (2007) Biosynthesis of gold nanoparticles assisted by Escherichia coli DH5 $\alpha$ and its application on direct electrochemistry of haemoglobin. Electrochemistry Communications 9(5): 1165-1170.

59. Attard G (2021) Biosynthesis of Platinum Nanoparticles by Escherichia coli MC4100: Can Such Nanoparticles Exhibit Intrinsic Surface Enantioselectivity?. Langmuir 28(11): 5267-5274.

60. Park Y, Hong YN, Weyers A, Kim YS, Linhardt RJ (2011) Polysaccharides and phytochemicals: a natural reservoir for the green synthesis of gold and silver nanoparticles. IET Nanobiotechnology 5(3): 69-78.

61. Ahmad A (2003) Extracellular biosynthesis of silver nanoparticles using the fungus Fusarium oxysporum. Colloids and Surfaces B Biointerfaces 28(4): 313-318.

62. Correa-Llantén DN, Muñoz-Ibacache SA, Castro ME, Muñoz PA, Blamey JM (2013) Gold nanoparticles synthesized by Geobacillus sp. strain ID17 a thermophilic bacterium isolated from Deception Island, Antarctica. Microbial Cell Factories 12(1): 75.

63. Yates MD (2021) Extracellular Palladium Nanoparticle Production using Geobacter sulfurreducens. ACS Sustainable Chemistry \& Engineering 9: 1165-1175.

64. Srivastava P, Kowshik M (2016) Anti-neoplastic selenium nanoparticles from Idiomarina sp. PR58-8», Enzyme and Microbial Technology 95: 192-200.

65. Fesharaki PJ (2010) Biosynthesis of selenium nanoparticles using Klebsiella pneumoniae and their recovery by a simple sterilization process. Braz J Microbiol 41(2): 461-466.

66. Mokhtari N (2009) Biological synthesis of very small silver nanoparticles by culture supernatant of Klebsiella pneumonia: The effects of visible-light irradiation and the liquid mixing process», Materials Research Bulletin 44(6): 1415-1421.

67. Mohseniazar M, Barin M, Zarredar $\mathrm{HH}$, Alizadeh S, Shanehbandi D (2011) Potential of Microalgae and Lactobacilli in Biosynthesis of Silver Nanoparticles. Bioimpacts 1(3): 149-152.

68. Visha P (2015) Biosynthesis and Structural Characteristics of Selenium Nanoparticles using Lactobacillus Acidophilus Bacteria by Wet Sterilization Process. IJAVST 4(1): 178-183.

69. Ali FA (2021) Effect of Titanium Nanoparticles 
Biosynthesis By Lactobacillus Crispatus On Urease, Hemolysin\& Biofilm Forming By Some Bacteria Causing Recurrent Uti In Iraqi Women. 10(9).

70. Dhoondia ZH, Chakraborty H (2012) Lactobacillus Mediated Synthesis of Silver Oxide Nanoparticles. Nanomaterials and Nanotechnology 2(15).

71. Jha AK, Prasad K, Kulkarni AR (2009) Synthesis of TiO2 nanoparticles using microorganisms. Colloids and Surfaces B Biointerfaces 71(2): 226-229.

72. Prasad K, Jha AK (2009) ZnO Nanoparticles: Synthesis and Adsorption Study. Natural Science 1(2).

73. Rathod V, Banu A (2012) Screening of Lactobacillus sp. for mediating the biosynthesis of silver nanoparticles from silver nitrate. IOSR J Pharm 2(2): 237-241.

74. Ramakritinan CM, Kaarunya E, Shankar S, Kumaraguru AK (2013) Antibacterial Effects of Ag, Au and Bimetallic (Ag-Au) Nanoparticles Synthesized from Red Algae. Solid State Phenomena.

75. Nair B (2002) Coalescence of Nanoclusters and Formation of Submicron Crystallites Assisted by Lactobacillus Strains. Crystal Growth \& Design 2(4): 293-298.

76. Gou Y (2015) Highly efficient in vitro biosynthesis of silver nanoparticles using Lysinibacillus sphaericus MR- 1 and their characterization. Science and technology of advanced materials 16(1).

77. Fdez-Gubieda ML (2013) Magnetite Biomineralization in Magnetospirillum gryphiswaldense: Time-Resolved Magnetic and Structural Studies. 7(4): 3297-3305.

78. Schübbe S (2003) Characterization of a Spontaneous Nonmagnetic Mutant of Magnetospirillum gryphiswaldense Reveals a Large Deletion Comprising a Putative Magnetosome Island. Journal of Bacteriology 185(19): 5779-5790.

79. Dennis AB (2020) Anaerobic Magnetite Production by a Marine Magnetotactic Bacterium. pp: 1-2.

80. Sharma N (2012) Exploitation of marine bacteria for production of gold nanoparticles. 11: 86.

81. Ramanathan R, O Mullane AP, Parikh RY, Smooker PM, Bhargava SK, et al. (2011) Bacterial kinetics-controlled shape-directed biosynthesis of silver nanoplates using Morganella psychrotolerans. Langmuir 27(2): 714-719.

82. Rajesh R (2011) Biological synthesis of copper/copper oxide nanoparticles. pp: 1991-1998.
83. Parikh RY, Singh S, Prasad BLV, Patole MS, Sastry M, et al. (2008) Extracellular Synthesis of Crystalline Silver Nanoparticles and Molecular Evidence of Silver Resistance from Morganella sp.: Towards Understanding Biochemical Synthesis Mechanism. ChemBio chem 9(9): 1415-1422.

84. Hasan S (2008) Bacterial Synthesis of Copper/Copper Oxide Nanoparticles: Ingenta Connect (6): 3191-3196.

85. Sable SV, Ranade S, Joshi S (2018) Role of AgNPs in the enhancement of seed germination and its effect on plumule and radicle length of Pennisetum glaucum. IET Nanobiotechnology 12(7): 922-926.

86. Thomas RA, Janardhanan RT, Varghese EV, Soniya J, Mathew, et al. (2014) Antibacterial properties of silver nanoparticles synthesized by marine Ochrobactrum sp. Brazilian Journal of Microbiology 45(4): 1221-1227.

87. Torres SK (2012) Biosynthesis of selenium nanoparticles by Pantoea agglomerans and their antioxidant activity. 14.

88. Kathiresan K, Manivannan S, Nabeel MA, Dhivya B (2009) Studies on silver nanoparticles synthesized by a marine fungus, Penicillium fellutanum isolated from coastal mangrove sediment. Colloids and Surfaces B: Biointerfaces 71(1): 13-137.

89. Chelladurai M (2013) Novel eco-friendly synthesis of titanium oxide nanoparticles by using Planomicrobium sp. and its antimicrobial evaluation. Der Pharmacia Sinica 4: 59-66.

90. Lengke MF (2021) Biosynthesis of Silver Nanoparticles by Filamentous Cyanobacteria from a Silver (I) Nitrate Complex. Langmuir 23(5): 2694-2699.

91. Lengke MF, Southam G (2005) The effect of thiosulfateoxidizing bacteria on the stability of the gold-thiosulfate complex. Geochimica et Cosmochimica Acta 69(15): 3759-3772.

92. Nasrin S (2009) Intra/Extracellular Biosynthesis of Silver Nanoparticles by an Au.: Ingenta Connect 5(3): 247-253.

93. Shivakrishna P (2013) Synthesis of Silver Nano Particles from Marine Bacteria Pseudomonas aerogenosa. ProQuest 1(2): 108-114.

94. Kumar V (2009) Plant-mediated synthesis of silver and gold nanoparticles and their applications - Kumar - 2009 - Journal of Chemical Technology \&amp; Biotechnology. Wiley Online Library 82(2): 151-157. 
95. Husseiny MI, El Aziz MA, Badr Y, Mahmoud MA (2007) Biosynthesis of gold nanoparticles using Pseudomonas aeruginosa. Spectrochimica Acta Part A: Molecular and Biomolecular Spectroscopy 67(3): 1003-1006.

96. Narayanan KB (2010) Biological synthesis of metal nanoparticles by microbes. Science Direct 156(1-2): 1-13.

97. Zhang W, Chen Z, Liu H, Zhang L, Gao P, et al. (2011) Biosynthesis and structural characteristics of selenium nanoparticles by Pseudomonas alcaliphila. B Biointerfaces 88(1): 196-201.

98. Shantkriti S, Rani P (2014) Biological synthesis of Copper nanoparticles using Pseudomonas fluorescens. 3(9): 374-383.

99. Syed B, Prasad NMN, Satish S (2016) Endogenic mediated synthesis of gold nanoparticles bearing bactericidal activity. Journal of Microscopy and Ultrastructure 4(3): 162-166.

100. Yadav A (2015) Extracellular biosynthesis of silver nanoparticles from Plant Growth Promoting Rhizobacteria Pseudomonas sp. Int J Curr Microbiol App Sci 4(8): 1057-1068.

101. Joerger R (2000) Biologically Produced SilverCarbon Composite Materials for Optically Functional Thin-Film Coatings. Advanced Materials 12(6): 407-409.

102. Klaus $\mathrm{T}$ (1999) Silver-based crystalline nanoparticles, microbially fabricated. PNAS 96(24): 13611-13614.

103. Slawson RM, Trevors JT, Lee H (1992) Silver accumulation and resistance in Pseudomonas stutzeri. Arch Microbiol 158(6): 398-404.

104. Ahmad J (2015) Nanotechnology-based inhalation treatments for lung cancer: state of the art. Nanotechnol Sci Appl 8: 55-66.

105. Ahmad A (2003) Extracellular Biosynthesis of Monodisperse Gold Nanoparticles by a Novel Extremophilic Actinomycete, Thermomonospora sp. Langmuir 19(8): 3550-3553.

106. Ahmad A (2003) Intracellular synthesis of gold nanoparticles by a novel alkalotolerant actinomycete, Rhodococcusspecies. Nanotechnology 14(7): 824-828.

107. He S, Zhang Y, Guo Z, Gu N (2008) Biological Synthesis of Gold Nanowires Using Extract of Rhodopseudomonas capsulate. Biotechnology Progress 24(2): 476-480.
108. He S, Guo Z, Zhang Y, Zhang S, Wang J, et al. (2007) Biosynthesis of gold nanoparticles using the bacteria Rhodopseudomonas capsulate. Materials Letters 61(18): 3984-3987.

109. Singh PK (2013) Biosynthesis of Gold Nanoparticles Using Bacteria. 18: 331-336.

110. Bai HJ, Zhang ZM, Guo Y, Yang GE (2009) Biosynthesis of cadmium sulfide nanoparticles by photosynthetic bacteria Rhodopseudomonas palustris. Colloids and Surfaces B: Biointerfaces 70(1): 142-146.

111. Holmes JD (1995) Energy-dispersive X-ray analysis of the extracellular cadmium sulfide crystallites of Klebsiella aerogenes. 163: 143-147.

112. Khanianipor A (2015) Extracellular Synthesis of Copper Nanoparticles using Culture Supernatants of Salmonella typhimurium. Oriental Journal of Chemistry 31: 527-529.

113. Konishi Y, Tsukiyama T, Ohno K, Saitoh N, Nomura T, et al. (2006) Intracellular recovery of gold by microbial reduction of $\mathrm{AuCl}_{4-}$ ions using the anaerobic bacterium Shewanella algae. Hydrometallurgy 81(1): 24-29.

114. Thakkar KN, Mhatre SS, Parikh RY (2010) Biological synthesis of metallic nanoparticles», Nanomedicine: Nanotechnology. Biology and Medicine 6(2): 257-262.

115. Marshall MJ (2006) Type Cytochrome-Dependent Formation of U(IV) Nanoparticles by Shewanella oneidensis. PLOS Biology 4(8): 268.

116. Raveendran P (2003) Completely "Green" Synthesis and Stabilization of Metal Nanoparticles. Journal of the American Chemical Society 125(46): 13940-13941.

117. Nanda A, Saravanan M (2009) Biosynthesis of silver nanoparticles from Staphylococcus aureus and its antimicrobial activity against MRSA and MRSE. Nanomedicine: Nanotechnology, Biology and Medicine 5(4): 452-456.

118. Nangia Y (2009) A novel bacterial isolates Stenotrophomonas maltophilia as living factory for synthesis of gold nanoparticles. Microbial Cell Factories 39.

119. Ceuvas R (2015) Extracellular Biosynthesis of Copper and Copper Oxide Nanoparticles by Stereum hirsutum, a Native White-Rot Fungus from Chilean Forests. 2015.

120. Zarina A (2014) Green Approach for Synthesis of Silver Nanoparticles from Marine Streptomyces- MS 26 
and Their Antibiotic Efficacy. ProQuest 6(10): 321-327.

121. Deshmukh (2011) Biosynthesis and Characterization of Manganese and Zinc Nanoparticles. EBSCOhost|80826679.

122. Chauhan R, Kumar A, Abraham J (2013) A Biological Approach to the Synthesis of Silver Nanoparticles with Streptomyces sp JAR1 and its Antimicrobial Activity. Scientia Pharmaceutica 81(2): 2.

123. Zonooz NF (2011) Extracellular biosynthesis of silver nanoparticles using cell filtrate of Streptomyces sp. ERI-3. 18(6): 1631-1635.

124. Korbekandi H, Asghari G, Jalayer SS, Jalayer MS, Bandegani M (2013) Nanosilver Particle Production Using Juglans Regia L. (Walnut) Leaf Extract. Jundishapur J Nat Pharm Prod 8(1): 20-26.

125. Jang GG (2014) Size tunable elemental copper nanoparticles: extracellular synthesis by thermoanaerobic bacteria and capping molecules. J Mater Chem C 3(3): 644-650.

126. Kasthuri J (2009) Phyllanthin-assisted biosynthesis of silver and gold nanoparticles: a novel biological approach. 11: 1075-1085.

127. Mukherji P (2017) Stenotrophomonas and Microbacterium: Mediated Biogenesis of Copper, Silver and Iron Nanoparticles-Proteomic Insights and Antibacterial Properties Versus Biofilm Formation. Journal of cluster science 28: 331-358.

128. Fayaz A, Balaji K, Girilal M, Yadav R, Kalaichelvan PT, et al. (2010) Biogenic synthesis of silver nanoparticles and their synergistic effect with antibiotics: a study against gram-positive and gram-negative bacteria. Nanomedicine: Nanotechnology, Biology and Medicine 6(1): 103-109.

129. Gericke M, Pinches P (2006) Biological synthesis of metal nanoparticles. Hydrometallurgy 83(1): 132-140.

130. Sangaru SS, Rai A, Ahmad A, Sastry M (2004) Biosynthesis of silver and gold nanoparticles from extracts of different parts of the geranium plant. Appl Nanosci 1: 69-77.

131. Solis DM (2014) Toward Ultimate Nanoplasmonics Modeling. 8 (8): 7559-7570.

132. Khan I (2019) Nanoparticles: Properties, applications and toxicities. Science Direct 12(7): 908931.
133. Pradhan N (2013) Facets of Nanotechnology as Seen in Food Processing, Packaging, and Preservation Industry. BioMed Research International 3.

134. Siddiqi KS, Husen A, Rao RAK (2018) A review on biosynthesis of silver nanoparticles and their biocidal properties. Journal of Nanobiotechnology 16(1): 14.

135. Jain N, Bhargava A, Majumdar S, Tarafdar JC, Panwar J (2011) Extracellular biosynthesis and characterization of silver nanoparticles using Aspergillus flavus NJP08: A mechanism perspective. Nanoscale 3(2): 635-641.

136. Maroofpour N, Alizadeh M, Hatami M, Asgari Lajayer B (2019) Biological Synthesis of Nanoparticles by Different Groups of Bacteria.

137. Late DJ (2013) Sensing Behavior of Atomically ThinLayered MoS2 Transistors. ACS Nano 7(6): 4879-4891.

138. Safari J, Zarnegar Z (2014) Advanced drug delivery systems: Nanotechnology of health design A review. Journal of Saudi Chemical Society 18(2): 85-99.

139. Kiessling F, Mertens ME, Grimm J, Lammers T (2014) Nanoparticles for imaging: top or flop? Radiology 273(1): 10-28.

140. Tallury P, Malhotra A, Byrne LM, Santra S (2010) Nanobioimaging and sensing of infectious diseases. Adv Drug Deliv Rev 62(4): 424-437.

141. Grasso G, Zane D, Dragone R (2019) Microbial Nanotechnology: Challenges and Prospects for Green Biocatalytic Synthesis of Nanoscale Materials for Sensoristic and Biomedical Applications. Nanomaterials 10(1): 11.

142. Kuznetsov AI (2011) Laser Fabrication of LargeScale Nanoparticle Arrays for Sensing Applications. ACS Nano 5(6): 4843-4849.

143. Zhu G (2013) Toward Large-Scale Energy Harvesting by a Nanoparticle-Enhanced Triboelectric Nanogenerator. Nano Letters 13(2): 847-853.

144. Baro M, Nayak P, Baby TT, Ramaprabhu S (2012) Green approach for the large-scale synthesis of metal/ metal oxide nanoparticle decorated multiwalled carbon nanotubes. J Mater Chem A 1(3): 482-486.

145. Feng J (2019) Translational formulation of nanoparticle therapeutics from laboratory discovery to clinical scale. Journal of Translational Medicine 17: 200.

146. Jacek P (2019) Molecular aspects of bacterial nanocellulose biosynthesis. Microb Biotechnol 12(4): 
633-649.

147. Ayano H, Kuroda M, Soda S, Ike M (2015) Effects of culture conditions of Pseudomonas aeruginosa strain RB on the synthesis of CdSe nanoparticles. J Biosci Bioeng 119(4): 440-445.

148. Gurunathan S (2009) Biosynthesis, purification and characterization of silver nanoparticles using Escherichia coli. Colloids Surf B Biointerfaces 74(1): 328-335.

149. Mohammed Fayaz A, Balaji K, Kalaichelvan PT, Venkatesan R (2009) Fungal based synthesis of silver nanoparticles--an effect of temperature on the size of particles. Colloids Surf B Biointerfaces, 74(1): 123-126.

150. Pimprikar PS, Joshi SS, Kumar AR, Zinjarde SS, Kulkarni SK (2009) Influence of biomass and gold salt concentration on nanoparticle synthesis by the tropical marine yeast Yarrowia lipolytica NCIM 3589. Colloids Surf B Biointerfaces 74(1): 309-316.

151. Abo Elsoud MM, Al Hagar OEA, Abdelkhalek ES, Sidkey NM (2018) Synthesis and investigations on tellurium myconanoparticles. Biotechnol Rep (Amst) 18: e00247.

152. Su Y, Lundholm N, Ellegaard M (2018) Effects of abiotic factors on the nanostructure of diatom frustulesranges and variability. Appl Microbiol Biotechnol 102(14): 5889-5899.

153. Rorrer GL, Chang $\mathrm{CH}$, Liu SH, Jeffryes C, Jiao J, Hedberg JA (2005) Biosynthesis of silicon-germanium oxide nanocomposites by the marine diatom Nitzschia frustulum. J Nanosci Nanotechnol 5(1): 41-49.

154. Raliya R, Singh Chadha T, Haddad K, Biswas P (2016) Perspective on Nanoparticle Technology for Biomedical Use. Current Pharmaceutical Design 22(17): 2481-2490.

155. Tiquia-Arashiro S, Rodrigues D (2016) Extremophiles: Applications in Nanotechnology. Springer International Publishing pp: 163-193.

156. Yokoyama $\mathrm{T}$ (2012) Nanoparticle Technology Handbook. $3^{\text {rd }}$ (Edn.), Elsevier.

157. Wang L, Hu C, Shao L (2017) The antimicrobial activity of nanoparticles: present situation and prospects for the future. Int J Nanomedicine 12: 1227-1249.

158. Fariq A, Khan T, Yasmin A (2017) Microbial synthesis of nanoparticles and their potential applications in biomedicine. J Appl Biomed 15(4): 241-248.

159. Seil JT, Webster TJ (2012) Antimicrobial applications of nanotechnology: methods and literature», Int J Nanomedicine 7: 2767-2781.

160. Sunkar S, Nachiyar CV (2012) Biogenesis of antibacterial silver nanoparticles using the endophytic bacterium Bacillus cereus isolated from Garcinia xanthochymus. Asian Pac J Trop Biomed 2: (12): 953959.

161. Sondi I, Salopek Sondi B (2004) Silver nanoparticles as antimicrobial agent: a case study on E. coli as a model for Gram-negative bacteria. J Colloid Interface Sci 275(1): 177-182.

162. Jabir NR, Tabrez S, Ashraf GM, Shakil S, Damanhouri GA, et al. (2012) Nanotechnology-based approaches in anticancer research. Int J Nanomedicine 7: 4391-4408.

163. Ashour AH (2018) Antimicrobial activity of metalsubstituted cobalt ferrite nanoparticles synthesized by sol-gel technique. Particuology 40: 141-151.

164. De Jong HK, Van der Poll T, Wiersinga WJ (2010) The systemic pro-inflammatory response in sepsis. J Innate Immun 2(5): 422-430.

165. Adhikari T, Kundu S, Biswas AAK, Tarafdar JC, Subba Rao A (2014) Effect of Zinc, Copper and Calcium Phosphate Nano Particles on Growth of Spirulina platensis. Natl Acad Sci Lett 37(3): 207-212.

166. Mohanpuria P, Rana N, Yadav S (2008) Biosynthesis of nanoparticles: Technological concepts and future applications. Journal of Nanoparticle Research 10: 507517.

167. Syed A, Saraswati S, Kundu GC, Ahmad A (2013) Biological synthesis of silver nanoparticles using the fungus Humicola sp. and evaluation of their cytoxicity using normal and cancer cell lines. Spectrochim Acta A Mol Biomol Spectrosc 114: 144-147.

168. Chauhan D (2011) In vitro and in vivo selective antitumor activity of a novel orally bioavailable proteasome inhibitor MLN9708 against multiple myeloma cells. Clin Cancer Res 17(16): 5311-5321. 